\title{
ANALISIS KESESUAIAN RENCANA KERJA DAN ANGGARAN (RKA) DENGAN TEMUAN INITIAL ASSESMENT AKREDITASI JOINT COMMISSION INTERNATIONAL (JCI) DI RUMAH SAKIT Dr. SOETOMO
}

\author{
Muhammad Jarno* Sudirman* \\ *Prodi Administrasi Rumah Sakit STIKES Yayasan Rumah Sakit Dr. Soetomo, \\ Muhammadjarno@gmail.com
}

\begin{abstract}
ABSTRAK
Pada 2016 Rumah Sakit Umum D Dr. Soetomo tengah melaksanakan penilaian akreditasi Joint Commission Internasional (JCI). Untuk mencapai kelulusan akreditasi JCI ada 16 standar yang harus dipenuhi oleh RSUD Dr.Soetomo. Pada penelitian awal yaitu pada bulan Januari 2016, terdapat beberapa temuan masalah yang dinilai oleh Tim Penilai Akreditasi JCI yang ada di RSUD Dr. Soetomo. Jika Rumah Sakit Umum Dr. Soetomo ingin lulus dalam penilaian akreditasi JCI maka pihak rumah sakit harus menyelesaikan temuan penilaian awal. Penelitian ini merupakan penelitian Inferensial yaitu suatu penelitian dengan melakukan analisis hubungan antar variabel dengan pengujian hipotesis. Peneliti menetapkan hipotesis tentang Adakah kesesuaian antara penggunaan anggaran Rumah Sakit terhadap penyelesaian Initial Assesment ?. Dalam pengujian hipotesis tersebut peneliti menggunakan Uji Chi Square. Peneliti menggunakan beberapa data primer antara lain, Rencana Kerja dan Anggaran, Data Usulan Kelompok Kerja FMS, dan data temuan JCI serta melakukan wawancara. Jumlah usulan Pokja FMS yang sesuai dengan temuan Initial Assesmment akreditasi JCI sebanyak 34 usulan sedangkan jumlah usulan yang tidak sesuai adalah sebanyak 78 usulan dari 112 usulan. Untuk jumlah RKA yang sesuai dengan Initial Assesment sebanyak 76 item, sedangkan yang tidak sesuai adalah sebanyak 135 item dari 211 rencana kerja. Pada uji Chi square nilai asymp signifikansinya $<0,05$ maka $\mathrm{H}_{0}$ diterima, maka dapat dikatakan bahwa tidak adanya kesesuaian antara penggunaan anggaran Rumah Sakit terhadap penyelesaian Initial Assesmen. Rencana Kerja dan Anggaran (RKA) yang tidak berhubungan untuk menjawab temuan Initial Assesment anggarannya jangan realisasikan karena bisa menjadi sumber pemborosan anggaran Rumah Sakit. RKA yang tidak sesuai dengan temuan anggarannya dapat dipangkas atau digunakan untuk menjawab temuan yang belum terjawab.
\end{abstract}

Kata kunci : JCI, Akreditasi, Anggaran

\section{ABSTRACT}

On 2016 General Hospital Dr.Soetomo the carrying out the judgments Joint Commission International (JCI) accreditation. To achieve graduation JCI accreditation is 16 standard to be protected by Dr.soetomo Hospital. In early research at January 2016, there are several problems findings assessed by the judges JCI accreditation in Hospital Dr.Soetomo. If General Hospital Dr. Soetomo want to graduate in judgment JCI accreditation and hospitals have to resolve the initial assessment. The research is research inferential namely a research by conducting an analysis of the relationship between variables with the testing of hypotheses. Researchers set has any hypothesis about conformity between the use of budget hospital against the completion of initial assessment?. In testing the hypotheses 
researchers used chi square test. Researchers used some documents secondary among others, work plan and budget (WPB), the working group fms proposal, and documents jci findings and conducted interviews. The number of proposals fms that working group in accordance with the findings initial assesmment jci accreditation is 34 proposals meanwhile the number of proposals which is not in accordance as many as 78 proposals from 112 proposal. For the number of rka that is in accordance with initial assessment some 76 items, while that is not in accordance as many as 135 items of 211 the work plan. By the experiment chi square value asymp signifikansinya $<0.05$ then $H_{0}$ accepted, it can be said that the absence of conformity of the use of the budget the hospital against the completion of initial assesmen. The work plan and the budget (WPB ) which has no relation to answer the findings of the initial assessment the budget do not do it because it might be a source of the waste of budget the hospital .Rka which is not in accordance with the findings can be trimmed the budget or used to answer a discovery that has not been answered.

Keywords: JCI, Accreditation, Budget

\section{PENDAHULUAN}

Rumah sakit merupakan institusi pelayanan kesehatan bagi masyarakat dengan karakteristik tersendiri yang dipengaruhi oleh perkembangan ilmu pengetahuan kesehatan, kemajuan teknologi, dan kehidupan sosial ekonomi masyarakat yang tetap mampu meningkatkan pelayanan yang lebih bermutu dan terjangkau oleh masyarakt agar terwujud derajat kesehatan yang setinggi-tingginya.

Kebutuhan masyarakat akan jasa layanan kesehatan semakin tinggi, hal ini disebabkan karena semakin tingginya kesadaran masyarakat akan kesehatan. Dalam memenuhi kebutuhan masyarakat akan jasa layanan kesehatan, maka rumah sakit harus selalu berusaha untuk memenuhinya dan harus dapat meningkatkan kemampuan dalam melakukan pelayanan jasa kesehatan. Bagi pemilik rumah sakit agar kegiatannya tetap berjalan dengan baik, maka peningkatan mutu dilakukan dengan menambah sumber daya yang berkualitas.

Upaya yang dilakukan kementerian kesehatan untuk meningkatkan mutu pelayanan adalah melalui kegiatan akreditasi rumah sakit, baik rumah sakit milik pemerintah ataupun swasta. Berdasarkan Undang-undang (UU) Nomor 44 tahun 2009 tentang Rumah Sakit Pasal 40 berbunyi "dalam upaya peningkatan mutu pelayanan, rumah sakit wajib dilakukan akreditasi secara berkala minimal 3 (tiga) tahun sekali". Akreditasi rumah sakit merupakan suatu proses dimana suatu lembaga yang independen, melakukan asesmen terhadap rumah sakit. Tujuannya adalah menentukan apakah rumah sakit tersebut memenuhi standar yang dirancang untuk memperbaiki keselamatan dan mutu pelayanan (Depkes, 2011).

Rumah Sakit Umum Daerah (RSUD) Dr. Soetomo merupakan rumah Sakit tipe A, dengan Visi "Menjadi Rumah Sakit yang Bermutu Internasional dalam Pelayanan, pendidikan dan Penelitian". Sedangkan Misinya "menyelenggarakan Pelayanan Kesehatan, Pendidikan dan Penelitian yang Profesional, Akuntabel yang Berorientasi pada Kastemer untuk Menuju Pelayanan kesehatan Berstandar Internasional". RSUD Dr. Soetomo memiliki kebijakan yang meliputi :

1. Perbaikan mutu pelayanan

2. Perbaikan Manajemen Sumber Daya Manusia (SDM) internal rumah sakit

3. Penataan kelembagaan (struktur dan sistem)

4. Pemantapan nilai dasar menjadi budaya organisasi

5. Penataan sistem akuntansi keuangan

6. Pengendalian biaya dan struktur anggaran 
7. Perbaikan manajemen logistik medik dan non medik

8. Penataan manajemen pendidikan klinik dan penelitian rumah sakit

9. Pengembangan aliansi strategis.

Pada tahun ini RSUD Dr. Soetomo tengah melaksanakan penilaian akreditasi Joint Commission Internasional (JCI). Untuk mencapai kelulusan akreditasi JCI ada 16 standar yang harus dipenuhi oleh RSUD Dr.Soetomo. Pada penelitian pada bulan Januari 2016, terdapat temuan temuan (Initial Assesment) yang dinilai oleh Tim Penilai Akreditasi JCI yang ada di RSUD Dr. Soetomo. Jika RSUD Dr. Soetomo ingin lulus dalam penilaian akreditasi JCI maka pihak rumah sakit harus memenuhi Initial Assesment.

Berikut adalah standar yang disurvei oleh Tim penilai akreditasi JCI beserta jumlah temuan atau Initial Assesment, sebagai berikut :

1. International Patient Safety Goals, terdapat 30 temuan.

2. Access to Care and Continuity of Care, terdapat 20 temuan

3. Patient and Family Rights, terdapat 3 temuan

4. Assessment of Patients, terdapat 44 temuan

5. Care of Patients, terdapat 44 temuan

6. Anesthesia and Surgical Care, terdapat 9 temuan

7. Medication Management and Use, 43 temuan

8. Patient and Family Education, terdapat 4 temuan

9. Quality Improvement and Patient Safety, terdapat 10 temuan

10. Prevention and Control of Infection, terdapat 63 temuan

11. Governance, Leadership and Direction, terdapat 19 temuan

12. Facility Management and Safety, terdapat 77 temuan

13. Staff Qualification and Education, terdapat 24 temuan

14. Management of Infromation, terdapat 21 temuan
15. Medical Proffesional Education, terdapat 3 temuan dan,

16. Human Subject Research Program, hanya terdapat 1 temuan.

Untuk memenuhi Initial Assesment dibuatlah Kelompok Kerja (Pokja). Pada setiap Pokja telah mengusulkan beberapa kebutuhan untuk memenuhi Initial Assesment, yang menjadi pertanyaan adalah apakah usulan-usulan dari setiap Pokja telah sesuai untuk memenuhi Initial Assesment ?. Oleh karena itu, peneliti akan mengangkat topik penelitian tentang "Analisis Kesesuaian Rencana Kerja dan Anggaran (RKA) dengan Temuan Initial Assesment akreditasi Joint Commission International (JCI) di Rumah Sakit Dr.Soetomo Tahun 2016".

\section{METODE PENELITIAN}

Penelitian ini merupakan penelitian Inferensial yaitu suatu penelitian dengan melakukan analisis hubungan antar variabel dan pengujian hipotesis. Peneliti menetapkan hipotesis tentang Adakah kesesuaian antara penggunaan anggaran Rumah Sakit terhadap penyelesaian Initial Assesment?. Dalam pengujian hipotesis tersebut peneliti menggunakan metode Uji Chi Square.

Berdasarkan pada kajian masalah dan kerangka konseptual yang telah dijelaskan, maka berikut adalah rancangan penelitian yang akan digunakan dalam penelitian ini, Penentuan alat (instrument) pengambilan data yang digunakan berupa Lembar Pengumpul Data dan Pedoman Wawancara. Cara pengumpulan pada lembar pengumpul data adalah dengan membuat table dokumen dengan kategori penilaian "(1) sesuai" dan "(2) tidak sesuai". Untuk wawancara adalah dengan melakukan wawancara kepada Kepala Kelompok Kerja Facility Management and Safety (FMS) berdasarkan pada panduan wawancara dan mengisi ketersediaan untuk menjadi narasumber. Pengolahan data yang dilakukan dengan pengolahan data menggunakan program aplikasi komputer Metode analisis penelitian 
menggunakan metode analisis Inferensial yang menggunakan Uji Chi Square Menyimpulkan dari hasil dan ringkasan

\section{Usulan Kelompok Kerja (Pokja) Facility Management and Safety (FMS)}

Untuk menunjang keberhasilan lulus dalam program Akreditasi JCI setiap Pokja membuat suatu program dan kegiatan kerja untuk menjawab temuan temuan Initial Assesment. Pada Pokja FMS telah melakukan beberapa usulan terkait Facility Management and Safety. Pokja FMS mengusulkan 114 kerja untuk dianggarkan. Dalam usulan tersebut Pokja FMS mengusulkan anggaran sebesar Rp. 18.835.374.200,00. Setelah usulan dibuat maka perlu dilakukan prioritas kerja yang dapat diselesaikan terlebih dahulu dan dapat dianggarkan. Yang me-lakkukan prioritas kegiatan adalah Poja FMS itu sendiri.

\section{Rencana Kerja dan Anggaran (RKA) Pergeseran RSUD Dr. Soetomo 2016}

Usulan yang telah dprioritaskan dan disetujui kemudian didokumentasi-kan dalam bentuk Rencana Kerja dan Anggaran (RKA). Pada penganggar-an untuk penyelesaian temuan JCI, RSUD Dr. Soetomo menyusun RKA yang bersifat insidentil atau yang disebut RKA Pergeseran RSUD Dr.Soetomo 2016. Untuk melaksana-kan program dan kegiatan diatas rumah sakit mengeluarkan anggaran sebesar Rp. 89.898.109.200,00. Program dan kegiatan tersebut ditargetkan selesai pada bulan Oktober karena pada bulan Oktober tim survei dari Akreditasi JCI akan menilai kembali. Menurut anggota Poka FMS pada bulan Angustus realisasi baru mencapai $25 \%$ dikarenakan masih dalam proses tender. Hambatan hambatan yang di hadapi menurut anggota Pokja FMS adalah masih lambanya penyerapan biaya dikarenakan banyaknya usulan yang harus diselesaikan. penelitian berupa hasil perhitungan jumlah usulan yang sesuai dengan teman masalah dan menganalisis Uji hipotesis.

\section{PEMBAHASAN}

Dalam pembahasan ini dibagi tig subbab untuk menjawab tujuan khusus, sebagai berikut :

Kesesuaian antara Usulan dengan temuan Initial Assesment Akreditasi JCI di RSUD Dr.Soetomo tahun 2016.

Tabel 1. Jumlah Kesesuaian Usulan Pokja FMS dengan Temuan Initial Assesment Akreditasi JCI RSUD Dr. Soetomo 2016.

\begin{tabular}{|l|l|l|}
\hline No & Kesesuaian & Jumlah \\
\hline 1. & Sesuai & 36 \\
\hline 2. & Tidak Sesuai & 78 \\
\hline Jumlah & $\mathbf{1 1 4}$ \\
\hline \multicolumn{2}{|l|}{ Sumber: Hasil olahan dari Temuan JCI dan Usulan }
\end{tabular}
Pokja FMS

Dari tabel diatas dapat dilihat jumlah usulan Pokja FMS yang sesuai dan yang tidak sesuai dengan temuan masalah akreditasi JCI. Jumlah usulan yang sesuai untuk mejawab temuan akreditasi JCI adalah sebanyak 36 usulan atau sebesar $31,58 \%$ dari seluruh usulan Pokja FMS, sedangkan jumlah usulan yang tidak sesuai adalah sebanyak 78 usulan atau jika dipersentasekan adalah $68,42 \%$ dari jumlah seluruh usulan dari pokja FMS.

Kesesuaian antara Output RKA dengan temuan Initial Assesment Akreditasi JCI di RSUD Dr.Soetomo tahun 2016.

Tabel 2 Jumlah Kesesuaian RKA Pergeseran 2016 dengan Temuan Initial Assesment Akreditasi JCI RSUD Dr.

Soetomo 2016 untuk Pokja FMS

\begin{tabular}{|c|c|c|}
\hline No & Kesesuaian & Jumlah \\
\hline 1. & Sesuai & 76 \\
\hline 2. & Tidak Sesuai & 135 \\
\hline \multicolumn{2}{|c|}{ Jumlah } & 211 \\
\hline
\end{tabular}


Tabel di atas merupakan tabel mengenai jumlah banyaknya RKA yang sesuai dan tidak sesuai. Jumlah kegiatan yang ada dalam Dokumen RKA Pergeseran RSUD Dr. Soetomo tahun 2016 untuk Pokja FMS adalah sebanyak 211 item. Dari seluruh item jumlah RKA yang sesuai atau berhubungan dengan temuan initial Assesment dari tataran Output adalah sebanyak 76 item atau 36,02\%, sedangkan yang tidak sesuai adalah sebanyak 135 item dan jika dipersentasekan menjadi $63,98 \%$. Jika diubah dalam bentuk jumlah nominal uang yang sesuai atau tidak sesuai, maka jumlah anggaran yang sesuai anara RKA dan temuan sebanyak Rp.20.380.438.200,00 atau sebesar $22,67 \%$, sedangkan RKA yang tidak sesuai sebanyak Rp.69.517.671.000,00 atau 77,33\% dari seluruh RKA untuk Pokja FMS sebanyak Rp. 89.898.109.200,00.

Jadi berdasarkan penjelasan diatas, maka Rumah Sakit mengeluarkan belanja anggaran rumah sakit sebesar Rp.69.517.671.000,00 tidak sesuai dengan hasil temuan Initial Assesment Akreditasi JCI Standar FMS. Rumah Sakit tidak dikatakan rugi namun anggaran tersebut menyimpang dari tujuan Output dan menyimpang dari tujuan utama pembuatan RKA Pergeseran 2016 yang fungsinya adalah menjawab temuan - temuan JCI mengenai standar FMS.

\section{Mengidentifikasi Hipotesis Penelitian}

Tabel 3analisis Chi-square Kesesuaian

RKA Pergeseran 2016 terhadap temuan Initial Assesment Akreditasi JCI

\begin{tabular}{|l|l|}
\hline Uraian & $\begin{array}{l}\text { Kesesuaian RKA dengan } \\
\text { temuan Initial Assesment } \\
\text { Akreditasi JCI Pokja FMS }\end{array}$ \\
\hline Chi-Square & $16,498^{\mathrm{a}}$ \\
\hline Df & 1 \\
\hline Asymp. Sig. & 0,000 \\
\hline $\begin{array}{l}\text { a. } 0 \text { cells }(0,0 \%) \text { have expected frequencies less } \\
\text { than 5. The minimum expected cell frequency } \\
\text { is 105,5. }\end{array}$ \\
Sumber: Hasil olahan Program Aplikasi
\end{tabular}

Berdasarkan tebel tersebut diketahui nilai Asymp siknifikan adalah 0,000 atau bisa dikatakan nilai asymp signifikansinya < dari 0,05. Pada bab sebelumnya tentang analisa data sudah dijelaskan jika nilai asymp signifikansinya $<0,05$ maka $\mathrm{H}_{0}$ diterima, maka dapat dikatakan bahwa tidak adanya kesesuaian antara RKA RSUD Dr.Soetomo terhadap penyelesaian Initial Assesmen.

\section{KESIMPULAN}

Dari pemaparan subbab pembahasan, maka dapat ditarik beberapa kesimpulan untuk menjawab

1. Jumlah usulan Pokja FMS yang sesuai dan yang tidak sesuai untuk mejawab temuan akreditasi JCI adalah sebesar $31,42 \%$ sedangkan jumlah usulan yang tidak sesuai adalah sebanyak sebesar $68,42 \%$, jadi disa dikatakan usulan dari Pokja FMS lebih banyak yang tidak sesuai.

2. Jumlah banyaknya RKA yang sesuai dengan temuan initial Assesment dari tataran Output

3. sebesar $36,02 \%$, sedangkan yang tidak sesuai adalah 63,98\%, maka bisa disimpulkan RKA tersebut lebih banyak yang tidak sesuai dengan temuan. Jika tetap direalisasikan rumah sakit melakukan pemborosan anggaran sebesar Rp.69.517.671.000,00.

4. Nilai Asymp siknifikan adalah 0,000 atau bisa dikatakan nilai asymp signifikansinya $<$ dari 0,05 , maka $\mathrm{H}_{0}$ diterima dan dapat dikatakan bahwa tidak adanya kesesuaian antara RKA RSUD Dr. Soetomo terhadap penyelesaian Initial Assesmen.

\section{SARAN}

Dalam hasil penelitian ini peneliti memberikan berbagai saran yang semoga dapat digunakan untuk membantu pengambilan keputusan di RSUD Dr. Soetomo, sebagai berikut:

1. Jika Rencana Kerja dan Anggaran (RKA) yang tidak berhubungan untuk 
menjawab temuan Initial Assesment anggarannya jangan realisasikan karena bisa menjadi sumber evektifitas penggunaan anggaran Rumah Sakit.

2. RKA yang tidak sesusai segera direvisi.

3. Diperlukan koordinasi lintas fungsi terhadapat semua Pokja JCI.

4. RKA yang tidak sesuai dengan temuan anggarannya dapat dipangkas atau digunakan untuk menjawab temuan yang belum terjawab.

5. Anggaran

Rp.69.517.671.000,00. yang tidak sesuai temuan Initial Assesment ini sebaiknya dialihfungsikan sebagai belanja operasional atau digunakan belanja kebutuhan belanja operasional di RSUD Dr. Soetomo.

6. Untuk RKA yang tidak sesuai dengan temuan Initial Assesment dan tidak direalisasikan namun dianggap penting untuk rumah sakit dapat diusulkan kembali pada Dokumen Perubahan Pelaksanaan Anggaran (DPA) Murni 2017 atau anggaran tahun berikutnya

7. Untuk kedepannya penelitian ini bisa dilanjutkan setelah realisasi RKA Pergeseran 2016 selesai 100\%.

\section{DAFTAR PUSTAKA}

Anggraini, Y., Putanta, Hendra.,2010. Anggaran Berbasis Kinerja: Penyusunan APBD Secara Komprehensif. Edisi Pertama.Yogyakarta: Unit Penerbit dan Percetakan Sekolah Tinggi Ilmu Manajemen YKPN.

Arikunto, Suharsimi., 2010. Manajemen Penelitian.Jakarta: Rineka Cipta.

Ariyanto, 2006. Pengolahan Data Statistik dengan SPSS 14. Jakarta: Salemba Infotek

Azwar, Saifuddin., 2010. Metode Penelitian. Yokyakarta: Pustaka Pelajar Offerset

JCI., 2011.Pedoman Survei Interna Joint Commission International RSUD Dr.Soetomo Edisi 4.
JCI., 2014. Joint Commission Intenational Accreditation Standars for Hospital Edition $5^{\text {th }}$.

KARS., 2011. Standar Akreitasi Rumah Sakit. Jakarta: Direktorat Jenderal Bina Upaya Kesehatan Republik Indonesia dengan Komisi Akreditasi Rumah Sakit (KARS).

Narbuko,Cholid., Achmadi, Abu., 2003. Metodologi Penelitian. Jakarta: Sinar Grafika Offset

Republik Indonesia., 2009. UndangUndang Nomor 44 Tahun 2009 tentang Rumah Sakit. Jakarta. Republik Indonesia

Ripublik Indonesia, Peraturan Menteri Kesehatan Nomor 56 Tahun 2014 tentang Klasifikasi dan Perizinan Rumah Sakit. Jakarta. Republik Indonesia

Ripublik Indoneisa, Peraturan Menteri Kesehatan Nomor 12 Tahun 2012 tentang Akreditasi Rumah Sakit. Jakarta. Republik Indonesia.

Raharjo, S., 2014. Cara Melakukan Uji Statistik Chi Square SPSS. http://www.konsistensi.com/2014 /12/cara-uji-chi-square-spss.html. (diakses 13 Mei 2016)

Sugiyono., 2011. Statistika untuk Penelitian. Bandung: Alfabeta

Suharyadi, Purwanto, S.K., 2009. Stastitika untuk Ekonomi dan Keuangan Modern Edisi Kedua. Jakarta: Salemba Empat , 2014. Tentang RSUD Dr. Soetomo.

http://rsudrsoetomo.jatimprov.go.i d/id/index.php/2014-11-19-04-3724/201 4-11-19-04-43-34 (diakses 2 Agustus 2016) , 2014. Visi dan Misi RSUD Dr.Soetomo. http://rsudrsoetomo.jatimprov.go. id/id/index.php/2014-11-19-0438-27 (diakses 2 Agustus 2016) 